\title{
"Profitability of commercial banks revisited: new evidence from oil and non-oil exporting countries in the MENA region"
}

\begin{tabular}{|c|c|c|}
\hline AUTHORS & \multicolumn{2}{|l|}{$\begin{array}{l}\text { Nermeen Abdullah } \\
\text { Yong Tan }\end{array}$} \\
\hline ARTICLE INFO & \multicolumn{2}{|c|}{$\begin{array}{l}\text { Nermeen Abdullah and Yong Tan (2017). Profitability of commercial banks } \\
\text { revisited: new evidence from oil and non-oil exporting countries in the MENA } \\
\text { region. Investment Management and Financial Innovations, 14(3), 62-73. } \\
\text { doi:10.21511/imfi.14(3).2017.06 }\end{array}$} \\
\hline DOI & \multicolumn{2}{|c|}{ http://dx.doi.org/10.21511/imfi.14(3).2017.06 } \\
\hline RELEASED ON & \multicolumn{2}{|l|}{ Wednesday, 11 October 2017} \\
\hline RECEIVED ON & \multicolumn{2}{|l|}{ Saturday, 24 June 2017} \\
\hline ACCEPTED ON & \multicolumn{2}{|l|}{ Tuesday, 22 August 2017} \\
\hline & \multicolumn{2}{|l|}{$(\mathrm{cc}) \overline{\text { EY-NC }}$} \\
\hline LICENSE & \multicolumn{2}{|c|}{$\begin{array}{l}\text { This work is licensed under a Creative Commons Attribution-NonCommercial } 4.0 \\
\text { International License }\end{array}$} \\
\hline JOURNAL & \multicolumn{2}{|c|}{ "Investment Management and Financial Innovations" } \\
\hline ISSN PRINT & \multicolumn{2}{|l|}{$1810-4967$} \\
\hline ISSN ONLINE & \multicolumn{2}{|l|}{$1812-9358$} \\
\hline PUBLISHER & \multicolumn{2}{|c|}{ LLC “Consulting Publishing Company "Business Perspectives" } \\
\hline FOUNDER & \multicolumn{2}{|c|}{ LLC "Consulting Publishing Company "Business Perspectives" } \\
\hline \multirow[b]{2}{*}{ NUMBER OF REFERENCES } & & $\begin{array}{ll}=-: \\
= \pm=-\end{array}$ \\
\hline & NUMBER OF FIGURES & NUMBER OF TABLES \\
\hline 42 & 2 & 6 \\
\hline
\end{tabular}

(C) The author(s) 2022. This publication is an open access article. 


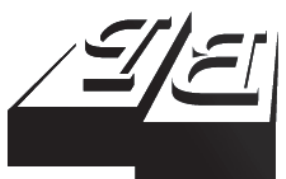

BUSINESS PERSPECTIVES

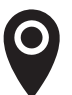

LLC "CPC "Business Perspectives" Hryhorii Skovoroda lane, 10, Sumy, 40022, Ukraine

www.businessperspectives.org

Received on: $24^{\text {th }}$ of June, 2017 Accepted on: $22^{\text {nd }}$ of August, 2017

(C) Nermeen Abdullah, Yong Tan, 2017

Nermeen Abdullah, M.Sc., Department of Accountancy, Finance and Economics, Huddersfield Business School, University of Huddersfield, Queensgate, Huddersfield, UK.

Yong Tan, Ph.D., Senior Lecturer Department of Accountancy, Finance and Economics, Huddersfield Business School, University of Huddersfield, Queensgate, Huddersfield, UK.
PROFITABILITY OF COMMERCIAL BANKS REVISITED: NEW EVIDENCE FROM OIL AND NON-OIL EXPORTING COUNTRIES IN THE MENA REGION

\begin{abstract}
This paper investigates the determinants of commercial bank profitability in oil and non-oil countries of the Middle East and North Africa (MENA) region using data from 11 countries over the period 2004-2014. Since banks are under no obligation to fill reports to Bankscope database, irregular reporting banks are omitted from the sample and the model is re-estimated using only regular reporting banks, and a comparative analysis between total banks' sample and regular reporting banks' sample is provided Using the two-step system GMM and fixed effects models, the results indicate that credit risk is negative and highly significant when irregular reporting banks are omitted from the sample, particularly in the non-oil group, unlike the oil countries case, which indicates that adding irregular reporting banks to the sample could lead to bias in some estimated coefficients if they constitute a considerable percentage of the total banks' sample. Diversification is a key determinant for profitability in oil countries. No enough evidence to support the impact of financial inclusion and financial openness on bank profitability. In addition, the global financial crisis has significantly affected bank profitability in oil countries. Several policy implications are provided to the bank management to follow based on each country group.
\end{abstract}

Keywords

JEL Classification bank profitability, irregular-reporting banks, MENA region

G21, C23

\section{INTRODUCTION}

The economy of the Middle East and North Africa (MENA) region is characterized by being a bank-based economy where the banking sector is dominating the financial system. The importance of the banking industry in the MENA region stems from the fact that bank deposits represent enormous share of GDP compared to other economies, which demonstrates the ability of these banks to attract large sums of money (EBRD, EIB, \& World Bank, 2016). The Global financial development database shows the level of bank deposits to GDP for the MENA region over the period 2004-2014 (see Appendix). It appears, that it is the highest compared to low-, middle-, and high-income countries, ranging between $65-80 \%$ of GDP. Further, MENA banking sector is one of the deepest across emerging economies in terms of credit provided to the private sector by banks as a ratio of GDP (Anzoategui, Peria, \& Rocha, 2010).

The MENA region also shares some common characteristics related to language, culture, and geography. However, despite all these similarities, others suggest that considering the MENA region as one homogenous region is misleading (Murjan \& Ruza, 2002). When looking at the region, we can notice that oil-producing countries are heavily de- 
pendent on the oil sector. Their financial systems are more integrated into global markets and are overly sensitive to fluctuations in oil prices. In addition, oil revenues are highly volatile which causes uncertainty in investors' expectations as most investments are oil-related investments. Besides, oil proceeds represent the main source of government spending (International Monetary Fund, 2016). Most banks are domestically owned with entry barriers and restrictions on foreign ownership, ranging between $0-49 \%$. They also have a fair share of state ownership and are well capitalized. On the contrary, non-oil exporting countries have a more diversified economy. They mainly rely on agriculture, foreign direct investment, and tourism among other sources of income. Although they have the largest share of stateowned banks, no limits are imposed on foreign ownership.

Additionally, financial inclusion and financial openness are believed to be important for profitability. Increased accessibility to banking services implies a better functioning financial intermediaries where more credit will be injected into the banking system to use and generate profits. Furthermore, studies have provided contradicting results regarding the impact of financial liberalization on bank performance (Bourgain, Pieretti, \& Zanaj, 2012; Barajas, Steiner, \& Salazar, 2000). Thus, a more extensive examination of these variables is undertaken.

This paper also looks at banks with regular reporting. Since banks are not obliged to fill reports to Bank scope, they might underreport some variables, mostly loan loss provisions, or might bypass some years when making losses which might result in biased estimated coefficients if these banks are included in the sample. Thus, this study considers a separate analysis for regular reporting banks or "good banks". To our knowledge, no studies have investigated this case. We utilize bank-level data from 11 MENA countries covering the period (2004-2014), using the two-step system generalized method of moments (GMM) and fixed effects models.

This study contributes to the literature as follows: first, it examines the determinants of bank profits in oil and non-oil countries. Second, we consider the influence of access to finance or financial inclusion and the degree of financial openness on profitability. Third, a separate analysis is considered for banks regularly reporting to Bankscope and the result is compared to those of the total banks' sample. The results show that adding irregular reporting banks to the total sample generates bias in the estimated coefficient of credit risk in non-oil countries as they represent a considerable percentage of total banks' sample. Through the analysis we do not find any evidence to support the influence of neither access to financial services nor the degree of financial openness on profitability. Finally, the findings report that the financial crisis has significantly reduced bank profitability in oil countries.

This paper is structured as follows: section 1 provides a summary of the literature, section 2 outlines the main determinants used, section 3 explains the data and methodology, section 4 shows the results and section last concludes.

\section{LITERATURE REVIEW}

\subsection{Literature on bank profitability in MENA region}

Short (1979), Bourke (1989) and Molyneux and Thornton (1992) provided the key determinants of profitability in the literature. They have considered a broad range of variables which can be categorized in internal and external factors. The internal determinants consist of the variables that are influenced by the administration's decisions and strategies such as size, capital, efficiency, risk, and liquidity, while the external determinants reflect how banks operate within the economic and legal environment such as concentration, economic growth and inflation. Furthermore, there has been a rise in the number of studies that examine bank profitability in the MENA region. The majority of studies focus on the comparison between the profitability of Islamic and conventional banks such as Zarrouk, Ben Jedidia, and Moualhi (2016), 
Olson and Zoubi (2016), Mokni and Rachdi (2014).

Ben Naceur and Omran (2011) examine the impact of adopting financial reforms and institutional developments in 10 MENA countries over the period (1989-2005) and find that these reforms have impacted bank performance and that the financial development indicators and the macroeconomic variables excluding inflation are insignificantly related to profitability, while capital and credit risk positively influence profits. Olson and Zoubi (2011) examine profitability in 10 MENA countries and find that banks with higher loans ratio, lower cost, higher capital, and are privately owned are more profitable. They recommend that bank mergers and free entry should be encouraged by regulators. Mirzaei, Moore, and Liu (2013) report that Middle Eastern countries have mainly higher profitability rates, especially the oil countries, compared to other emerging and advanced countries, and also find a significant negative relationship between market concentration and profitability. Farazi, Feyen, and Rocha (2013) examine bank ownership in 9 non-GCC countries in the MENA region and find that private banks are more profitable, more efficient and have less non-performing loans ratio than state-owned banks confirming the conclusion reached by Ben Naceur and Goaied (2008) that private banks outperform state-owned banks when investigating commercial banks in Tunisia. Ben Naceur and Goaied (2008) also conclude that profitability is associated with higher capital and large overheads. Besides, Ghosh (2016) examines the effect of the Arab spring turmoil on risk and return of MENA banks and notices that the political turmoil, which occurred from 2011 onwards reduced profitability by $0.2 \%$ and raised risk by $0.4 \%$.

\section{DETERMINANTS OF BANK PROFITABILITY AND VARIABLE SELECTION}

\subsection{Bank-specific determinants}

Size: measured by using the natural logarithm of total assets (in millions of US dollars). Large sized banks can raise capital more cheaply and achieve more profitability. However, higher operational and bureaucratic costs could result in diseconomies of scale (Pasiouras \& Kosmidou, 2007).

Capital: measured by total equity to total assets ratio. Higher capital ratio provides a safety net against losses and bankruptcy, and reduces the cost of borrowing (Athanasoglou, Brissimis, \& Delis, 2008). Nevertheless, the conventional risk-return trade-off could be displayed, through which higher capital will drive banks to be less inclined to take risk, and will have lower returns (Tan \& Floros, 2012a).

Credit risk: measured by loan loss provisions to total loans ratio. Risk typically lowers profitability since banks who undertake more risk experience higher number of loan defaults.

Liquidity: measured by total loans to total assets ratio. It is considered as a safe haven against a decrease in liabilities' side or to finance the increase in assets' side. Conversely, others argue that withholding liquidity is a burden on banks as it is considered wasted loanable funds (Olson \& Zoubi, 2011).

Efficiency: overhead cost to total assets ratio is used. Overheads include personnel expenses and other non-interest operating expenses. It reflects how efficient the bank management is in operating at a low cost, thus a negative relationship is expected. However, others find a positive relationship which could be due to higher salaries paid to personnel which is reflected in improvements in productivity and therefore higher profitability (Tan \& Floros, 2012b).

Diversification: is measured by non-interest income to gross revenue ratio. Diversification leads to economies of scope which results in lower costs and higher profits (Tan \& Floros, 2012b).

\subsection{Industry-specific determinants}

Herfindahl index: the Herfindahl-Hirschman index is used to investigate the impact of market power on profitability. It is defined as the sum of squared market shares of all banks in the industry. According to the (SCP) hypothesis, higher concentration will push banks to collude and earn monopoly profits. Bourke (1989), Molyneux 
and Thornton (1992) find a positive relationship between concentration and profitability. However, Berger (1995) argues that this positive relationship is a result of correlation with other variables and after controlling for them he finds a negative relationship.

Ownership: we build a dummy variable for banks' public ownership if the public sector owns more than $50 \%$ of bank capital. A negative relationship is expected since state-owned banks, run by bureaucratic management, tend to be less cost efficient and have larger number of personnel compared to their private counterparts.

Nationality: a dummy variable captures foreign ownership of banks if more than $50 \%$ of the capital is owned by foreigners. Demirgüç-Kunt and Huizinga (1999) find, that foreign banks are more profitable in developing countries since they are more technologically advanced relative to domestic banks.

Access to financial services (financial inclusion): measures the potential of individuals to access financial services (i.e. the breadth of the financial system). It is proxied by the number of commercial bank branches per 100,000 adults. Čihák, Demirgüç-Kunt, Feyen, and Levine (2013) introduce four dimensions for the financial system which are the depth, breadth, efficiency and stability. The literature has examined all these dimensions except breadth for their influence on bank profitability (Demirgüç-Kunt \& Huizinga, 1999; Tan, 2016; Tan \& Anchor, 2016). Increasing breadth suggests that more people would have access to banking services which would lead to more funds be available for banks to generate profits.

Chinn-Ito index: we use the Chinn-Ito index (KAOPEN) developed by Chinn and Ito (2006, 2008) to measure the degree of financial openness. It is based on binary variables that codify the information of the IMF's Annual Report on Exchange Arrangements and Exchange Restrictions (AREAER) and is intended to capture the openness in capital transactions. Bourgain et al. (2012) examine the impact of financial openness on bank risktaking behavior in MENA area and find that higher openness intensifies competition, and triggers banks to undertake excessive risks and reduces prof- it margins. Luo, Tanna, and De Vita (2016) examine the impact of financial openness on bank profit efficiency and risk using both Chinn-Ito index and the financial freedom index in 140 countries and find that financial openness lowers profit efficiency directly and increases risk through profitability channel. Conversely, Barajas et al. (2000) report that financial liberalization and the capital inflows that followed the openness of the capital account had a positive impact on profitability of Colombian banks.

\subsection{Macroeconomic determinants}

Inflation: is measured by the annual percentage of average consumer prices. According to Perry (1992), inflation affects profitability positively or negatively depending on whether inflation is anticipated or unanticipated. If anticipated, banks can promptly adjust interest rates and thus a positive impact is expected. Nevertheless, if inflation is unanticipated, banks face uncertainty and fail to timely adjust interest rates

GDP growth: real annual GDP growth rate is used to measure economic growth. A positive relationship is expected since economic booms are associated with increases in lending activities and positive expectations about the economy (Chronopoulos, Liu, McMillan, \& Wilson, 2015).

Crisis: we implement a dummy variable to capture the effect of global financial crisis on MENA area during 2007-2009. No study has tested the impact of the crisis on profitability in oil and non-oil countries before.

\subsection{Variable selection}

The return on average assets (ROAA) is utilized as a measure of profitability since it is the most widely used measure in the literature (Athanasoglou et al., 2008). ROAA is the ratio of net income to average total assets, and it shows the ability of bank management to earn income from bank's assets. Figure 1 shows the ROAA for oil and non-oil countries of the MENA region. Profitability of oil countries is far higher than those of non-oil countries, nevertheless profits slumped heavily for oil countries during the financial crisis, unlike the non-oil countries whose profits smoothed normally. Table 1 shows the variable selection for our paper. 


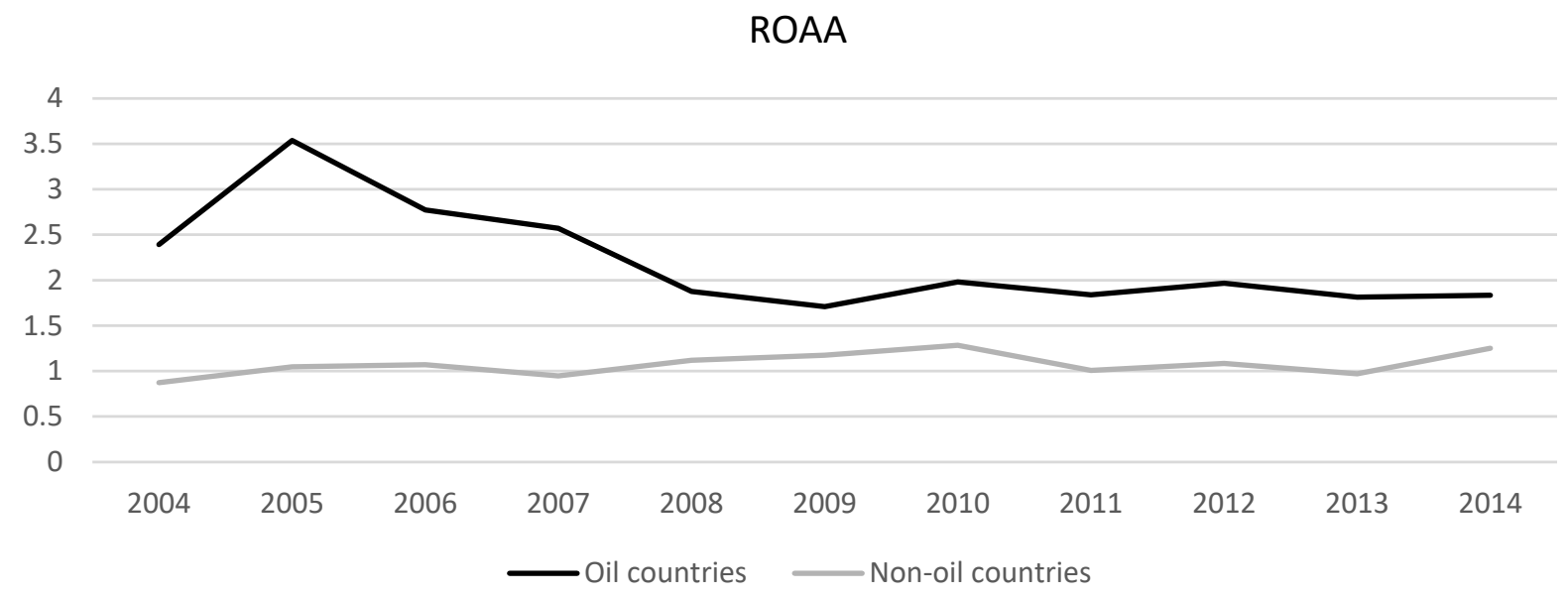

Figure 1. The profitability of oil and non-oil countries of MENA region over the period 2004-2014

\section{DATA AND METHODOLOGY}

\subsection{Data}

Our data sample covers 11 countries from the MENA region over the period 2004-2014. The sample is divided into oil countries (Algeria, Kuwait, Oman, Qatar, Saudi Arabia and United Arab Emirates) and non-oil countries (Egypt, Jordan, Lebanon, Morocco, and Tunisia). Since the dataset is missing some observations, we opt for an unbalanced panel dataset consisting of 126 commercial banks for all countries sample, 53 banks for oil countries and 73 banks for non-oil countries $^{1}$. As mentioned above, banks might bypass reporting to Bankscope in years when profits are falling or having bad numbers for some variables such as loan loss provisions, and thus we are keen to re-estimate the series with "good banks". Therefore, the regular reporting sample

1 We follow Tan (2016), and Lee and Hsieh (2013) in excluding banks with less than 3 consecutive years of observations.

Table 1. Summary of the variable selection

\begin{tabular}{|c|c|c|c|}
\hline Variable & Measurement & Expected sign & Source \\
\hline \multicolumn{4}{|c|}{ Dependent variable } \\
\hline ROAA & Net income/average total assets & & Bankscope \\
\hline \multicolumn{4}{|c|}{ Independent variables } \\
\hline \multicolumn{4}{|l|}{ Bank-specific } \\
\hline Size & Natural logarithm of total assets & $+/-$ & Bankscope \\
\hline Capital & Total equity/ total assets & $+/-$ & Bankscope \\
\hline Credit risk & Loan loss provisions/ total loans & $+1-$ & Bankscope \\
\hline Liquidity & Total loans/ total assets & - & Bankscope \\
\hline Efficiency & Overheads/ total assets & $+/-$ & Bankscope \\
\hline Diversification & Non-interest income/ gross revenue & + & Bankscope \\
\hline \multicolumn{4}{|c|}{ Industry-specific } \\
\hline Herfindahl index & Herfindahl-Hirschman index & $+/-$ & Authors' calculations \\
\hline Ownership & dummy variable $=1$ if public sector owns $>50 \%$ & - & Bankscope \\
\hline Nationality & dummy variable $=1$ if foreigners own $>50 \%$ & + & Bankscope \\
\hline Access & Bank branches per 100,000 adults & + & GFDD \\
\hline Chinn-Ito index & A proxy of the degree of capital account openness & $+/-$ & Chinn and Ito $(2006,2008)$ \\
\hline \multicolumn{4}{|c|}{ Macroeconomic variables } \\
\hline Inflation & Annual \% of average consumer prices & $+/-$ & $\mathrm{IMF}$ \\
\hline GDP growth & Real GDP growth rate & + & $\mathrm{IMF}$ \\
\hline Crisis & dummy variable = 1 for years: 2007, 2008, 2009 & - & - \\
\hline
\end{tabular}


Table 2. Descriptive statistics by country category

\begin{tabular}{|c|c|c|c|c|c|c|c|c|c|c|c|c|c|c|c|}
\hline \multirow{2}{*}{ Variable } & \multicolumn{5}{|c|}{ All countries } & \multicolumn{5}{|c|}{ Oil countries } & \multicolumn{5}{|c|}{ Non-oil countries } \\
\hline & Obs & Mean & SD & $\operatorname{lin}$ & Max & Obs & INT & SD & Min & $\operatorname{lax}$ & Dbs & Mean & SD & Min & Иах \\
\hline & & & & & & & & & 17 & & & & .26 & 9.99 & 21 \\
\hline Size & 57 & 8.42 & 1.46 & & & 537 & 0.03 & 1.46 & 16 & & 720 & & 1.32 & 4.88 & 1.07 \\
\hline & 257 & 12.1 & 6.82 & -1.62 & 87.22 & t & 14.93 & 7.14 & 0.77 & 6.83 & 720 & & 5.73 & -1.62 & 7.22 \\
\hline Cres & 1229 & 1.02 & 2.08 & -9.15 & 43.36 & 534 & 0.979 & 1.58 & -8.8 & 4.75 & 695 & 6 & 2.4 & -9.15 & 3.36 \\
\hline & & & & & & & & & & & & & & & \\
\hline Effic & 1255 & 1.74 & 0.981 & 0.009 & 1 & 5 & 1.53 & 0.782 & 0.288 & & 719 & & 1.08 & 0.009 & 11 \\
\hline Dive & ...... & & & & & & & & & & & & & & \\
\hline & 1386 & 25.4 & 913.2 & 859.24 & 5279 & 583 & 2282.4 & 817.01 & 1439 & 4224.8 & 803 & 1666.1 & 892.05 & 859.24 & 5 \\
\hline & & & & & & & & & & & & & & 3.91 & \\
\hline & 386 & & 1 & & & 58 & 1 & 1 & -1.19 & & 803 & 0. & 1.4 & -1.19 & \\
\hline & 00 & & & & & 583 & & & & & & & 67 & & 16.24 \\
\hline GDP growth & 1386 & 4.89 & 3.93 & -7.08 & 26.17 & 583 & 5.36 & 5.15 & -7.08 & 26.17 & 803 & 4.55 & 2.68 & -1.92 & 10.3 \\
\hline
\end{tabular}

consists of 99 banks for all countries, 45 banks for oil countries and 54 banks for non-oil countries. Fitch-IBCA Bankscope (BSC) database is the principal source of data. The World Economic Outlook Database of the IMF is used to obtain data for the GDP growth and inflation. The Global Financial Development Database (GFDD) of the World Bank, built by Čihák, Demirgüç-Kunt, Feyen, and Levine (2012), is used to obtain data for access to financial services. Table 2 shows the descriptive statistics for our variables. Banks in oil countries have nearly twice the return on assets of their counterparts in non-oil countries. They are also better capitalized, more illiquid, highly concentrated, have greater openness level and have less access to banking services compared to banks in non-oil countries.

\subsection{Methodology}

We adopt a linear dynamic panel model following Athanasoglou et al. (2008). According to Baltagi (2001) the use of least square estimators is criticized for producing biased and inconsistent estimated coefficients due to persistency in the model confirmed by studies of Berger et al. (2000) and Athanasoglou et al. (2008), which would lead to correlation problems between the lagged dependent variable and the unobservable individual effects. Therefore, the system generalized method of moments (GMM) is employed to overcome problems of profit persistence, unobserved heterogeneity, endogeneity, autocorrelation and omitted variable bias. Equation (1) represents the linear dynamic model as follows:

$$
\begin{aligned}
& \Pi_{i t}=c+\delta \cdot \Pi_{i, t-1}+\sum_{j=1}^{J} \beta_{j} X_{i t}^{j}+\sum_{l=1}^{L} \beta_{l} X_{i t}^{l}+ \\
& +\sum_{m=1}^{M} \beta_{m} X_{i t}^{m}+v_{i t}+\mu_{i t},
\end{aligned}
$$

where $\Pi_{i t}$ refers to the return on assets of bank $\mathrm{i}$ at time $\mathrm{t}$ and $\Pi_{i, t-1}$ represents the lagged dependent variable. $\delta$ is the speed of adjustment to equilibrium and its value varies between 0 and 1 . A value close to 0 means no persistence which implies a strong competition while a value close to 1 means a highly persistent industry with low competition. $X_{i t}^{j}$ represent the bank-specific factors, $X_{i t}^{l}$ represent the industry-specific factors while $X_{i t}^{m}$ represent the macroeconomic variables. $v_{i t}$ indicates the unobserved bank-specific error term and $\mu_{i t}$ is the idiosyncratic error.

Athanasoglou et al. (2008) also followed in modelling capital as an endogenous variable, since higher profits may lead to higher capital (i.e. causality could work in both directions), and risk as a predetermined variable in light of the rules set by central banks for the levels of loan loss provisions to be set at the beginning of each period. In addition, instrumenting the endogenous variable by two-period lagged levels and the predetermined variable by one-period lagged levels produces better esti- 
mates. We control for macroeconomic shocks such as the Arab spring transition period, captured by year dummies covering the years from 2011-2014. We use the system generalized method of moments (GMM) estimator developed by Arellano and Bover (1995) and Blundell and Bond (1998), which outperforms the Arellano and Bond (1991) difference estimator. This estimator employs additional moment conditions through which the level equation is instrumented using lagged differences and the differenced equation is instrumented using lagged levels. We use the two-step system GMM since it produces better results. Windmeijer (2005) corrected standard errors is also used since the standard errors of the two system GMM are seriously downward biased.

The validity of the model is assessed using two specification tests. Firstly, the Arellano and Bond (1991) serial autocorrelation test which validates the absence of autocorrelation in the idiosyncratic error. Secondly, the Hansen test of over-identifying restrictions to validate the instruments of the model ${ }^{2}$. We firstly use total banks dataset to estimate all countries, oil, and non-oil countries, and then we use the regular reporting dataset. Since the cross-sectional observations ' $\mathrm{N}$ ' might be relatively lower than the number of instruments specifically in oil countries, the fixed effects model is used to give robust results.

\section{EMPIRICAL RESULTS}

Table 3 and 4 present the empirical results of the model. Separate estimation results are reported using "total banks" and "regular reporting banks" samples respectively. The F-test shows an overall goodness of fit. Hansen test shows no evidence of over-identifying restrictions, implying the validity of the instruments used. Arellano and Bond serial autocorrelation test shows the absence of second order serial autocorrelation which means that the model is consistent. The estimation results show a significant yet small coefficient for lagged dependent variable (ROAA) for all countries and oil countries while insignificant for non-oil countries in all specifications. This implies that banks in
MENA region operate in fairly competitive market structures. Turning to bank-specific variables, capital is positive and significant for non-oil countries in both samples, which is in line with the findings of Athanasoglou et al. (2008).

For oil countries, risk is negative and significant in both samples, which means that irregular reporting doesn't cause bias in the estimated coefficients in general and risk in particular ${ }^{3}$. For non-oil countries, risk is weakly significant with a small coefficient for the total banks sample, while it becomes very significant and is tripled in value for the regular reporting sample. This means that irregular reporting banks result in biased estimated coefficients $s^{4}$. Liquidity is negatively related to profitability for non-oil countries using "total banks" sample. This is in accordance with Chronopoulos et al. (2015) who find that higher liquidity is important to secure against liquidity risk. Efficiency is negative and significant in oil countries using total banks sample and is robust which is in line with Mirzaei et al. (2013). Diversification is positively related to profitability in oil countries in all specifications, while it is significant in nonoil countries using the regular reporting sample. This means that economies of scope are evident in MENA banks and particularly in oil countries.

Turning to industry-specific factors, most variables are insignificant. Access to financial services and financial openness are found to be insignificant, which implies that having increased access to banking services or more financially integrated economy is irrelevant to profitability. For macroeconomic variables, inflation is positive and significant in all countries model using total sample only, which means that overall, banks can properly adjust interest rates. Finally, the financial crisis has significantly reduced profitability in oil countries than in the non-oil countries, which could be due to the sharp drop in oil prices and liquidity shortfalls in global markets (Khamis et al., 2010). However, the impact in non-oil countries is milder due to their reliance on different sources of income such as remittances, FDI, and trade channels through which the crisis was mildly transmit-

2 A cross-correlation matrix, available upon request, is performed to ensure that no multicollinearity issues exist.

3 This might be because irregular reporting banks constitute a small proportion of total banks in the sample (around 15\%) which means that they are ineffective in causing bias to estimated coefficients if included in the model.

4 The proportion of irregular reporting banks in non-oil countries is $26 \%$ of total banks sample. 
Table 3. GMM estimation results with ROAA as independent variable (total banks sample)

\begin{tabular}{|c|c|c|c|c|c|c|}
\hline \multirow{3}{*}{$\begin{array}{l}\text { Variable } \\
\text { L. ROAA }\end{array}$} & \multirow{2}{*}{\multicolumn{2}{|c|}{$\begin{array}{c}\text { All countries } \\
\text { Coefficient t-statistics }\end{array}$}} & \multirow{2}{*}{\multicolumn{2}{|c|}{$\begin{array}{c}\text { Oil countries } \\
\text { Coefficient t-statistics }\end{array}$}} & \multirow{2}{*}{\multicolumn{2}{|c|}{$\begin{array}{c}\text { Non-oil countries } \\
\text { Coefficient t-statistics }\end{array}$}} \\
\hline & & & & & & \\
\hline & $0.148^{* *}$ & 2.39 & $0.148^{* *}$ & 2.04 & 0.144 & 1.3 \\
\hline Size & -0.032 & -0.25 & -0.26 & -0.98 & 0.201 & 1.61 \\
\hline Capital' & $0.141^{* * *}$ & 4.05 & 0.061 & 1.46 & $0.135^{* * *}$ & 2.68 \\
\hline Credit risk & $-0.148^{* * *}$ & -2.64 & $-0.239^{* *}$ & -2.28 & $-0.092^{*}$ & -1.71 \\
\hline Liquidity & $-0.017 * * *$ & -2.78 & 0.01 & 0.79 & $-0.018^{* *}$ & -2.00 \\
\hline Efficiency & -0.324 & -1.25 & $-0.69^{*}$ & -1.98 & -0.044 & -0.15 \\
\hline Diversification & $0.035^{* * *}$ & 3.77 & $0.052^{* * *}$ & 4.56 & 0.013 & 1.63 \\
\hline Herfindahl index & $0.0004 *$ & 1.87 & 0.0002 & 0.54 & 0.0001 & 0.49 \\
\hline Ownership & -0.464 & -0.49 & -0.539 & -0.69 & 0.378 & 0.51 \\
\hline Nationality & -0.772 & -1.11 & -0.391 & -0.55 & 0.282 & 0.39 \\
\hline Access & -0.002 & -0.11 & 0.038 & 0.7 & -0.005 & -0.3 \\
\hline Chinn-Ito index & -0.047 & -0.34 & -0.121 & -0.5 & -0.155 & -1.24 \\
\hline Inflation & $0.017^{* *}$ & 2.35 & 0.005 & 0.3 & 0.018 & 1.53 \\
\hline GDP growth & 0.012 & 1.51 & -0.003 & -0.23 & $0.033^{*}$ & 1.89 \\
\hline Crisis & $-0.106^{* *}$ & -2.00 & $-0.263^{* *}$ & -2.23 & $-0.15^{*}$ & -1.96 \\
\hline Constant & -0.165 & -0.09 & 1.77 & 0.44 & -1.83 & 41.08 \\
\hline F-test & $9.54^{* * *}$ & - & $11.12^{* * *}$ & - & $9.81^{* * *}$ & - \\
\hline Hansen $^{\mathrm{a}}$ & 0.109 & - & 0.59 & - & 0.331 & - \\
\hline AR $(2)^{\mathrm{b}}$ & $z=0.93$ & $P=0.35$ & $z=0.44$ & $P=0.662$ & $z=0.51$ & $P=0.609$ \\
\hline No. of observations & 1087 & - & 474 & - & 613 & - \\
\hline No. of banks & 126 & - & 53 & - & 73 & - \\
\hline
\end{tabular}

Notes: ${ }^{*}{ }^{* *}$ and ${ }^{* * *}$ are significance levels at $10 \%, 5 \%$ and $1 \%$, respectively. F-test indicates the overall goodness of fit. ${ }^{1}$ Capital is instrumented using two period lagged levels. ${ }^{a}$ Hansen is the p-value of Hansen test for over-identifying restrictions. ${ }^{\mathrm{b}}$ Arellano and bond second order serial autocorrelation test $\left(H_{0}\right.$ : no autocorrelation).

Table 4. GMM estimation results with ROAA as independent variable (regular reporting sample)

\begin{tabular}{|c|c|c|c|c|c|c|}
\hline \multirow{3}{*}{$\begin{array}{l}\text { Variable } \\
\text { L. ROAA }\end{array}$} & \multirow{2}{*}{\multicolumn{2}{|c|}{$\begin{array}{c}\text { All countries } \\
\text { Coefficient t-statistics }\end{array}$}} & \multirow{2}{*}{\multicolumn{2}{|c|}{$\begin{array}{c}\text { Oil countries } \\
\text { Coefficient t-statistics } \\
\end{array}$}} & \multirow{2}{*}{\multicolumn{2}{|c|}{$\begin{array}{c}\text { Non-oil countries } \\
\text { Coefficient t-statistics }\end{array}$}} \\
\hline & & & & & & \\
\hline & $0.151^{* *}$ & 2.01 & $0.135^{*}$ & 1.86 & 0.113 & 0.80 \\
\hline Size & -0.087 & -0.45 & -0.301 & -1.23 & 0.031 & 0.15 \\
\hline Capital" & $0.117^{* * *}$ & 3.68 & 0.032 & 0.86 & $0.174^{* *}$ & 2.05 \\
\hline Credit risk & $-0.338^{* * *}$ & -3.66 & $-0.276^{*}$ & -1.92 & $-0.357 * * *$ & -2.80 \\
\hline Liquidity & $-0.015^{* *}$ & -2.04 & -0.008 & -0.43 & -0.009 & -0.79 \\
\hline Efficiency & -0.363 & -1.24 & -0.486 & -1.28 & -0.263 & -0.71 \\
\hline Diversification & $0.042 * * *$ & 4.68 & $0.058^{* * *}$ & 6.11 & $0.028^{* *}$ & 2.34 \\
\hline Herfindahl index & $0.0005^{* *}$ & 2.09 & -0.0002 & -0.55 & -0.00005 & -0.13 \\
\hline Ownership & 0.316 & 0.31 & -1.66 & -1.38 & 1.093 & 1.51 \\
\hline Nationality & -0.677 & -1.27 & -0.61 & -0.68 & -0.369 & -0.86 \\
\hline Access & -0.003 & -0.14 & 0.025 & 0.41 & 0.011 & 0.49 \\
\hline Chinn-Ito index & -0.068 & -0.46 & -0.12 & -0.31 & -0.069 & -0.41 \\
\hline Inflation & 0.015 & 1.25 & 0.001 & 0.05 & 0.017 & 1.37 \\
\hline GDP growth & -0.006 & -0.43 & 0.009 & 0.44 & 0.018 & 0.55 \\
\hline Crisis & $-0.188^{* * *}$ & -2.64 & $-0.321 * *$ & -2.40 & -0.109 & -1.18 \\
\hline Constant & 0.422 & 0.25 & 4.57 & 1.52 & -0.811 & -0.37 \\
\hline F-test & $14.67 * * *$ & - & $10.20^{* * *}$ & - & $25.90^{* * *}$ & - \\
\hline Hansen & 0.167 & - & 0.947 & - & 0.687 & - \\
\hline$A R(2)^{b}$ & $z=0.58$ & $P=0.563$ & $z=0.13$ & $P=0.897$ & $z=0.07$ & $P=0.946$ \\
\hline No. of observations & 918 & - & 420 & - & 498 & - \\
\hline No. of banks & 99 & - & 45 & - & 54 & - \\
\hline
\end{tabular}

Notes: ${ }^{*}{ }^{* *}$ and ${ }^{* * *}$ are significance levels at $10 \%, 5 \%$ and $1 \%$, respectively. F-test indicates the overall goodness of fit. ${ }^{1}$ Capital is instrumented using two period lagged levels. ${ }^{\text {a }}$ Hansen is the $\mathrm{p}$-value of Hansen test for over-identifying restrictions. ${ }^{\text {b Arel- }}$ lano and bond second order serial autocorrelation test (H0: no autocorrelation). 
Table 5. Fixed effects results (total banks sample)

\begin{tabular}{|c|c|c|c|c|c|c|}
\hline \multirow{3}{*}{$\begin{array}{ll} & \text { Variable } \\
\text { Size }\end{array}$} & \multirow{2}{*}{\multicolumn{2}{|c|}{$\begin{array}{c}\text { All countries } \\
\text { Coefficient t-statistics }\end{array}$}} & \multirow{2}{*}{\multicolumn{2}{|c|}{$\frac{\text { Oil countries }}{\text { Coefficient t-statistics }}$}} & \multirow{2}{*}{\multicolumn{2}{|c|}{$\frac{\text { Non-oil countries }}{\text { Coefficient t-statistics }}$}} \\
\hline & & & & & & \\
\hline & -0.008 & -0.05 & -0.218 & -1.21 & 0.18 & 1.2 \\
\hline Capital & $0.059^{* *}$ & 2.44 & $0.089 * * *$ & 3.40 & $0.045^{*}$ & 1.76 \\
\hline Credit risk & $-0.14^{* *}$ & -2.28 & $-0.20^{* *}$ & -2.49 & -0.105 & -1.62 \\
\hline Liquidity & $-0.015^{* *}$ & -2.01 & -0.001 & -0.12 & $-0.014^{*}$ & -2.00 \\
\hline Efficiency & -0.07 & -0.27 & $-0.529 * *$ & -2.17 & 0.142 & 0.36 \\
\hline Diversification & $0.02 * * *$ & 2.91 & $0.038^{* * *}$ & 3.90 & 0.005 & 0.93 \\
\hline Herfindahl index & -0.0001 & -1.14 & 0.0002 & 0.92 & $-0.0002^{*}$ & -1.8 \\
\hline Access & 0.02 & 0.92 & $-0.089 * *$ & -2.63 & 0.008 & 0.25 \\
\hline Inflation & $0.019^{* *}$ & 2.14 & 0.006 & 0.54 & 0.001 & 0.12 \\
\hline GDP growth & 0.015 & 1.48 & $0.021^{*}$ & 1.84 & $0.06^{* * *}$ & 3.22 \\
\hline Crisis & $-0.196^{* * *}$ & -3.34 & $-0.293^{* * *}$ & -2.83 & -0.138 & -1.47 \\
\hline Constant & 1.2 & 0.76 & $3.41^{*}$ & 1.76 & -0.606 & -0.36 \\
\hline F-test & $5.59^{* * *}$ & - & $8.38^{* * *}$ & - & $2.78^{* * *}$ & - \\
\hline No. of observations & 1214 & - & 528 & - & 686 & - \\
\hline No. of banks & 126 & - & 53 & - & 73 & - \\
\hline
\end{tabular}

Notes: ${ }^{*}{ }^{* *}$ and ${ }^{* *}$ are significance levels at $10 \%, 5 \%$ and $1 \%$, respectively. F-test indicates the overall goodness of fit. t-statistics are based on Heteroskedasticity-robust standard errors.

Table 6. Fixed effects results (regular reporting sample)

\begin{tabular}{|c|c|c|c|c|c|c|}
\hline \multirow{2}{*}{ Variable } & \multicolumn{2}{|c|}{ All countries } & \multicolumn{2}{|c|}{ Oil countries } & \multicolumn{2}{|c|}{ Non-oil countries } \\
\hline & \multicolumn{2}{|c|}{ Coefficient t-statistics } & \multicolumn{2}{|c|}{ Coefficient t-statistics } & \multicolumn{2}{|c|}{ Coefficient t-statistics } \\
\hline Size & -0.055 & -0.34 & $-0.318^{*}$ & -1.75 & 0.172 & 1.00 \\
\hline Capital & $0.054^{* *}$ & 2.27 & $0.087^{* * *}$ & 3.43 & 0.04 & 1.63 \\
\hline Credit risk & $-0.227^{* * *}$ & -2.85 & $-0.229^{* *}$ & -2.35 & $-0.209^{* *}$ & -2.09 \\
\hline Liquidity & -0.012 & -1.37 & -0.0008 & -0.06 & -0.012 & -1.2 \\
\hline Efficiency & -0.099 & -0.31 & $-0.665^{* * *}$ & -3.02 & 0.221 & 0.45 \\
\hline Diversification & $0.022^{* * *}$ & 2.70 & $0.038^{* * *}$ & 3.63 & 0.008 & 1.4 \\
\hline Herfindahl index & -0.0001 & -0.76 & 0.0003 & 1.33 & $-0.0002^{*}$ & -1.79 \\
\hline Access & 0.028 & 1.11 & $-0.098^{* * *}$ & -2.90 & 0.012 & 0.34 \\
\hline Inflation & 0.014 & 1.59 & 0.004 & 0.30 & -0.001 & -0.1 \\
\hline GDP growth & 0.012 & 1.03 & $0.024^{* *}$ & 2.09 & $0.053^{* *}$ & 2.45 \\
\hline Crisis & $-0.21^{* * *}$ & -3.40 & $-0.289^{* *}$ & -2.47 & -0.084 & -0.98 \\
\hline Constant & 1.48 & 0.82 & $4.42^{* *}$ & 2.18 & -0.75 & -0.38 \\
\hline F-test & $8.50^{* * *}$ & - & $14.87^{* * *}$ & - & $4.44^{* * *}$ & - \\
\hline No. of observations & 1017 & - & 465 & - & 552 & - \\
\hline No. of banks & 99 & - & 45 & - & 54 & - \\
\hline
\end{tabular}

Notes: ${ }^{*},{ }^{* *}$ and $^{* * *}$ are significance levels at $10 \%, 5 \%$ and $1 \%$, respectively. F-test indicates the overall goodness of fit. t-statistics are based on Heteroskedasticity-robust standard errors.

ted (Griffith-Jones \& Ocampo, 2009).

Besides, fixed effects model is used as a robustness check for the same model specifications. Table 5 and 6 summarize the estimation results in oil and non-oil countries using total banks and regular reporting samples respectively. Ownership, nation- ality, and financial openness variables are omitted from the model since they are time-invariant variables ${ }^{5}$. The results generated from the fixed effects model confirms the findings of the GMM as follows: 1) Credit risk is significant in oil countries using both samples while it is insignificant for non-oil countries when total banks sample is

5 Financial openness represented by Chinn-Ito index is constant in some countries. 
used and it gains significance when irregular reporting banks are omitted from the sample. This strengthens our conclusion, that adding irregular reporting banks, especially when they constitute a considerable percentage, to the sample creates bias in credit risk. 2) Liquidity is significant in non-oil countries when total banks sample is used. 3) Diversification is only robust in oil countries. 4) Inflation is significant in the overall model only using total sample. 5) Oil countries have been significantly more affected by the financial crisis than non-oil countries. It is worth noting, that access to financial services is unexpectedly found to be significantly negatively related to profits in oil countries in both samples, which suggests that having wider access to finance could reduce profitability, however, no support for this result by the system GMM model so no conclusion can be drawn.

\section{CONCLUDING REMARKS AND POLICY IMPLICATIONS}

This paper examines the determinants of bank profitability in oil and non-oil countries of the MENA region during the period 2004-2014. It also introduces new variables to the literature and provides a comparative analysis between total banks' sample and regular reporting banks' sample. Using the two-step system GMM with corrected Windmejir standard errors and fixed effects models, the results suggest that capital is important to profitability when considering all countries. Credit risk is strong and significant when irregular reporting banks are omitted from the sample particularly in non-oil countries, which leads us to conclude that adding irregular reporting banks to the sample could lead to bias in some estimated coefficients if they constitute a considerable percentage of the total sample. In addition, diversification is found to be a key determinant for profitability in oil countries. Access to financial services is only significant and negative in oil countries when fixed effects model is used while the degree of financial openness variable fails to gain significance in all models. Finally, the financial crisis has significantly affected profitability in oil countries. These results provide evidence for the importance of distinguishing between oil and non-oil exporting countries when examining determinants of bank profitability.

This study yields several policy implications. First, there is a pressing need for bank managers to improve the quality of risk management in the banking industry in non-oil countries through enhanced asset allocation and uncertainty management. Second, banks in oil countries should put emphasis on diversifying their products and services. Further research should be directed towards examining whether Islamic finance windows in commercial banks affect bank profitability and, if so, to what extent the impact varies between oil and non-oil countries.

\section{ACKNOWLEDGEMENTS}

The authors would like to thank Johan Rewilak for his valuable comments and suggestions. The firstnamed author would also like to thank Erasmus Mundus UNetBA project for their financial support. Any remaining errors are our own.

\section{REFERENCES}

1. Anzoategui, D., Peria, M. S., \& Rocha, R. R. (2010). Bank Competition in the Middle East and Northern Africa Region. Review of Middle East Economics and Finance, 6(2). https://doi. org/10.2202/1475-3693.1313

2. Arellano, M., \& Bond, S. (1991). Some tests of specification for panel data: Monte carlo evidence and an application to employment equations. The Review of Economic Studies, 58(2), 277-297. https://doi. org/10.2307/2297968.

3. Arellano, M., \& Bover, O. (1995). Another look at the instrumental variable estimation of errorcomponents models. Journal of Econometrics, 68(1), 29-51. https://doi.org/10.1016/03044076(94)01642-D.

4. Athanasoglou, P. P., Brissimis, S. N., \& Delis, M. D. (2008). Bankspecific, industry-specific and macroeconomic determinants of bank profitability. Journal of 
International Financial Markets, Institutions \& Money, 18(2), 121 136. https://doi.org/10.1016/j. intfin.2006.07.001.

5. Baltagi, B.H., 2001. Econometric Analysis of Panel Data (2nd ed.) Chichester: John Wiley \& Sons.

6. Barajas, A., Steiner, R., \& Salazar, N. (2000). The impact of liberalization and foreign investment in colombia's financial sector. Journal of Development Economics, 63(1), 157-196. https://doi.org/10.1016/S03043878(00)00104-8

7. Ben Naceur, S., \& Goaied, M. (2008). The determinants of commercial bank interest margin and profitability: evidence from Tunisia. Frontiers in Finance and Economics, 5(1), 106-130.

8. Ben Naceur, S., \& Omran, M. (2011). The effects of bank regulations, competition, and financial reforms on banks' performance. Emerging Markets Review, 12(1), 1-20. https://doi. org/10.1016/j.ememar 2010.08.002

9. Berger, A. N. (1995). The profitstructure relationship in Banking-Tests of market-power and efficient-structure hypotheses. Journal of Money, Credit \& Banking, 27(2), 404-431. https:// doi.org/10.2307/2077876

10. Berger, A. N., Bonime, S. D., Covitz, D. M., \& Hancock, D. (2000). Why are bank profits so persistent? the roles of product market competition, informational opacity, and regional/ macroeconomic shocks. Journal of Banking and Finance, 24(7), 12031235. https://doi.org/10.1016/ S0378-4266(99)00124-7

11. Blundell, R., \& Bond, S. (1998). Initial conditions and moment restrictions in dynamic panel data models. Journal of Econometrics, 87(1), 115-143. https://doi.org/10.1016/S03044076(98)00009-8

12. Bourgain, A., Pieretti, P., \& Zanaj, S. (2012). Financial openness, disclosure and bank risk-taking in MENA countries. Emerging Markets Review, 13(3), 283-300. https://doi.org/10.1016/j.ememar.2012.01.002
13. Bourke, P. (1989). Concentration and other determinants of bank profitability in Europe, North America and Australia. Journal of Banking and Finance, 13(1), 65-79. https://doi.org/10.1016/03784266(89)90020-4

14. Chinn, M. D., \& Ito, H. (2006). What matters for financial development? Capital controls, institutions, and interactions. Journal of Development Economics, 81(1), 163-192. https://doi. org/10.1016/j.jdeveco.2005.05.010

15. Chinn, M. D., \& Ito, H. (2008). A New Measure of Financial Openness. Journal of Comparative Policy Analysis: Research and Practice, 10(3), 309-322. https://doi. org/10.1080/13876980802231123

16. Chronopoulos, D. K., Liu, H., McMillan, F. J., \& Wilson, J. O. S. (2015). The dynamics of US bank profitability. The European Journal of Finance, 21(5), 426-443. https://doi.org/10.1080/135184 7X.2013.838184

17. Čihák, M., Demirgüç-Kunt, A., Feyen, E., \& Levine, R. (2012). Benchmarking financial systems around the world. World Bank Policy Research Working Paper 6175. Washington, DC: The World Bank. https://doi. org/10.1596/1813-9450-6175

18. Čihák, M., Demirgüç-Kunt, A., Feyen, E., \& Levine, R. (2013). Financial development in 205 economies, 1960 to 2010. (NBER Working Paper 18946). Cambridge, MA: National Bureau of Economic Research.

19. Demirgüç-Kunt, A., \& Huizinga, H. (1999). Determinants of commercial bank interest margins and profitability. The World Bank Economic Review, 13(2), 379-408. https://doi.org/10.1093/ wber/13.2.379

20. EBRD (European Bank for Reconstruction and Development), EIB (European Investment Bank), \& World Bank (2016). What's Holding Back the Private Sector in MENA? Lessons from the Enterprise Survey. European Bank for Reconstruction and Development, European Investment Bank, and World Bank.
21. Farazi, S., Feyen, E., \& Rocha, R. (2013). Bank Ownership and Performance in the Middle East and North Africa Region. Review of Middle East Economics and Finance, 9(2). https://doi. org/10.1515/rmeef-2012-0025

22. Ghosh, S. (2016). Political transition and bank performance: How important was the Arab Spring? Journal of Comparative Economics, 44(2), 372-382. https:// doi.org/10.1016/j.jce.2015.02.001

23. Griffith-Jones, S., \& Ocampo, J. A. (2009). The financial crisis and its impact on developing countries. Brasilia: United nations development programme (UNDP). International policy centre for inclusive growth (IPC-IG).

24. International Monetary Fund (2016). Economic Diversification in Oil-Exporting Arab Countries.

25. Khamis, M., Senhadji, A., Hasan, M., Kumah, F., Prasad, A., \& Sensenbrenner, G. (2010). Impact of the global financial crisis on the Gulf Cooperation Council countries and challenges ahead. Washington, D.C.: International Monetary Fund.

26. Lee, C., \& Hsieh, M. (2013). The impact of bank capital on profitability and risk in Asian banking. Journal of International Money and Finance, 32(1), 251281. https://doi.org/10.1016/j. jimonfin.2012.04.013

27. Luo, Y., Tanna, S., \& De Vita, G. (2016). Financial openness, risk and bank efficiency: Crosscountry evidence. Journal of Financial Stability, 24, 132148. https://doi.org/10.1016/j. jfs.2016.05.003

28. Mirzaei, A., Moore, T., \& Liu, G. (2013). Does market structure matter on banks' profitability and stability? Emerging vs. advanced economies. Journal of Banking and Finance, 37(8), 2920-2937. https://doi.org/10.1016/j.jbankfin.2013.04.031

29. Mokni, R. B., \& Rachdi, H. (2014). Assessing the bank profitability in the MENA region. International Journal of Islamic and Middle Eastern Finance and Management, 7(3), 305-332. https://doi. org/10.1108/imefm-03-2013-0031 
30. Molyneux, P., \& Thornton, J. (1992). Determinants of European bank profitability: A note. Journal of Banking and Finance, 16(6), 1173-1178. https://doi. org/10.1016/0378-4266(92)90065-8

31. Murjan, W., \& Ruza, C. (2002). The competitive nature of the Arab Middle Eastern banking markets. International Advances in Economic Research, 8(4), 267-274. https://doi.org/10.1007/ BF02295501

32. Olson, D., \& Zoubi, T. A. (2011). Efficiency and bank profitability in MENA countries. Emerging Markets Review, 12(2), 94-110. https://doi.org/10.1016/j.ememar.2011.02.003

33. Olson, D., \& Zoubi, T. (2016). Convergence in bank performance for commercial and Islamic banks during and after the Global Financial Crisis. The Quarterly Review of Economics and Finance. https://doi.org/10.1016/j. qref.2016.06.013

34. Pasiouras, F., \& Kosmidou, K. (2007). Factors influencing the profitability of domestic and foreign commercial banks in the European Union. Research in International Business and Finance, 21(2), 222-237. https://doi. org/10.1016/j.ribaf.2006.03.007

35. Perry, P. (1992). Do banks gain or lose from inflation? Journal of Retail Banking, 14(2), 25-30.

36. Short, B. K. (1979). The relation between commercial bank profit rates and banking concentration in Canada, Western Europe, and Japan. Journal of Banking and Finance, 3(3), 209-219. https://doi. org/10.1016/0378-4266(79)90016-5

37. Tan, Y. (2016). The impacts of risk and competition on bank profitability in China. Journal of International Financial Markets, Institutions and Money, 40, 85-110. https://doi.org/10.1016/j.intfin.2015.09.003

38. Tan, Y., \& Anchor, J. (2016). Stability and profitability in the Chinese banking industry: evidence from an auto-regressive-distributed linear specification. Investment Management and Financial Innovations, 13(4), 120-128. https:// doi.org/10.21511/imfi.13(4).2016.10
39. Tan, Y., \& Floros, C. (2012a). Bank profitability and GDP growth in China: A note. Journal of Chinese Economic and Business Studies, 10(3), 267-273. https://doi.org/10. 1080/14765284.2012.703541

40. Tan, Y., \& Floros, C. (2012b). Bank profitability and inflation: The case of China. Journal of Economic Studies, 39(6), 675-696. https://doi. org/10.1108/01443581211274610

41. Windmeijer, F. (2005). A finite sample correction for the variance of linear efficient twostep GMM estimators. Journal of Econometrics, 126(1), 25-51. https://doi.org/10.1016/j.jeconom.2004.02.005

42. Zarrouk, H., Ben Jedidia, K., \& Moualhi, M. (2016). Is Islamic bank profitability driven by same forces as conventional banks? International Journal of Islamic and Middle Eastern Finance and Management, 9(1), 46-66. https://doi.org/10.1108/imefm-12-2014-0120

\section{APPENDIX}

\section{Bank deposits to GDP (\%)}

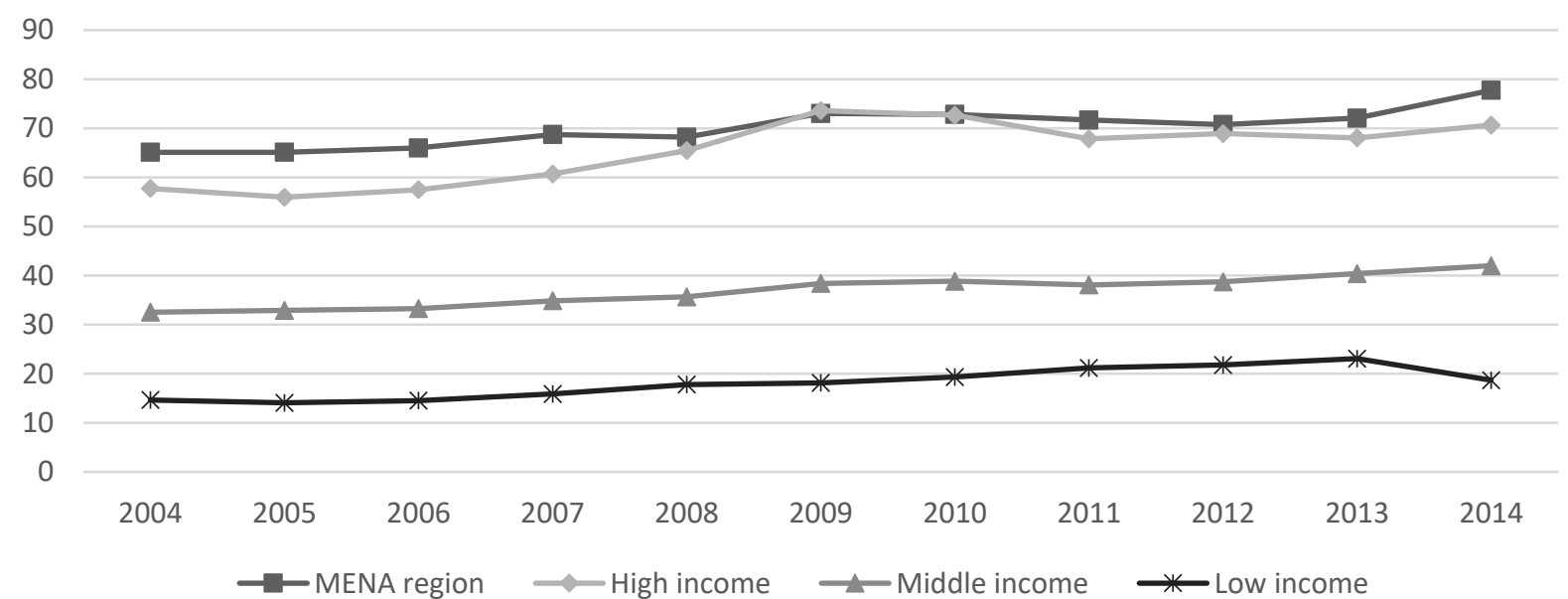

Figure 1a. Bank deposits to GDP for the MENA region over the period 2004-2014 